\title{
TEMPLE LOOTING IN CAMBODIA
}

\author{
Anatomy of a Statue Trafficking Network
}

\author{
Simon Mackenzie* and Tess Davis
}

Qualitative empirical studies of the illicit antiquities trade have tended to focus either on the supply end, through interviews with looters, or on the demand end, through interviews with dealers, museums and collectors. Trafficking of artefacts across borders from source to market has until now been something of an evidential black hole. Here, we present the first empirical study of a statue trafficking network, using oral history interviews conducted during ethnographic criminology fieldwork in Cambodia and Thailand. The data begin to answer many of the pressing but unresolved questions in academic studies of this particular criminal market, such as whether organized crime is involved in antiquities looting and trafficking (yes), whether the traffic in looted artefacts overlaps with the insertion of fakes into the market (yes) and how many stages there are between looting at source and the placing of objects for public sale in internationally respected venues (surprisingly few).

Keywords: trafficking, smuggling, cultural heritage, cultural property, cultural objects, antiquities, organized crime, transnational crime

\section{Introduction: from Source to Market, but How?}

Compared to other types of commodity traffic, in drugs, wildlife or even human beings, relatively little reliable empirical data have previously been gathered and published about the process of 'trafficking' in antiquities. Scholars of the international criminal market in cultural objects have access to a number of analyses of what we might characterize as the two ends of the global supply chain, in the form of studies of 'source' and 'market', but comparatively little about how looted cultural objects actually move from the ground to the international market buyer (see Brodie et al. 2013 for a literature review of evidence-based studies in this field). With limited exceptions, the available data have clustered around looters who take objects from important archaeological sites (Staley 1993; Paredes Maury 1996; van Velzen 1996; Matsuda 1998; Farchakh Bajjaly 2008a; 2008b) and dealers, museums and collectors around the world who provide the destinations for these stolen artefacts as part of their general acquisitive practices (Gill and Chippindale 1993; Chippindale and Gill 2000; Nørskov 2002; Mackenzie 2005; Davis 2011; Brodie and Bowman Proulx 2013).

In empirical terms, the few exceptions to these studies of the two ends of the chain essentially have been limited to a modest body of important investigative journalism, which understandably tends not to adopt a conventional academic-theoretical approach (Watson 1997; Atwood 2004; Watson and Todeschini 2006; Felch and

*Simon Mackenzie and Tess Davis, Trafficking Culture, SCCJR, School of Social and Political Sciences, University of Glasgow, Ivy Lodge, 63 Gibson Street, Glasgow G12 8LR, UK; simon.mackenzie@glasgow.ac.uk. 
Frammolino 2011). There is nothing in this field of study, however, which approximates the sort of global trafficking research that is emerging in anthropology, history or international relations (e.g. van Schendel and Abraham 2005; Nordstrom 2007; Bruns and Miggelbrink 2012), or in criminology for other international trafficking problems (e.g. Kelly et al. 2005; Hornsby and Hobbs 2007; Lee 2011), and so we are left with something of a black hole in our understanding of illicit antiquities trafficking networks. This article aims to begin to fill that hole.

Speculation on the likely structure of antiquities trafficking networks has evolved over the last three decades in the literature. An early writer in this field set out what he perceived to be a role-based structure to the movement of looted cultural objects from source to market. These stages included (1) looters ('local diggers'), (2) 'black market middlemen' and (3) 'local or foreign dealers' (Bator 1982: 292). More recently, Campbell has undertaken an analysis of secondary data and proposed a four-stage network structure: (1) looter, (2) early-stage intermediary, (3) late-stage intermediary and (4) collector (Campbell 2013). Polk has simultaneously produced a similar network outline: (1) 'extractors', (2) 'middlemen', (3) 'dealers' and (4) 'buyers' (Polk 2014). Polk also notes that his and other models refer to activity mainly taking place in the 1980s and 1990s and that conditions of globalization such as the growth in Internet sales, as well as more attention now paid to looting during conflict, would require adjustments to the model to ensure a contemporary fit. Other writers have produced models with a regional focus, in which the main roles above are again identified with some local inflections (Kersel 2007: 86-7).

We can see clear continuity and convergence in these various expressions of the constituent network roles. Interestingly, both of the Campbell and Polk analyses pick up on the importance of a type of middleman or dealer role that involves a particular individual having the capacity to 'face both ways' up and down the network, as it were, with a criminal face when looking down and a legitimate face when looking up. This is the particular type of international fencing that is necessary to allow the early-stage criminality of trafficking and looting to link up with the later-stage trading, which takes place in the 'grey market' (Mackenzie 2005; Bowman 2008) of apparently legitimate and often highly public deals involving auction houses, dealers, museums and collectors. The fence who 'faces both ways' is therefore the personification of a sanitizing portal for loot, taking it by reaching down the trafficking chain with a dirty hand and passing it onwards up the supply chain with an apparently clean one. As such, he is of fundamental importance in regulatory analysis of this illicit market. He is Janus-one face looking into the illicit past of an artefact and one looking into its public future where that dark past is concealed-the point of transition, or gateway between local looting and the international art market. Several examples of alleged, and in some cases convicted, occupants of the Janus role can be found in the case study literature on this market. We identify a similar Janus in the Cambodian traffic in the outline that follows.

In respect of the fit of the data and analysis presented here with contemporary theory on forms of groups and networks in other types of organized crime, there is both continuity and conflict. An article recently published in this journal by Lo sets out a progression of organizational analysis of Asian organized crime groups, with an emphasis on Chinese Triads (Lo 2010). Lo describes the 'structure-control' perspective, which emphasizes 'structural and subcultural control' through which 'triad societies were 
able to compel their members to run illicit activities' (Lo 2010: 852). This perspective has been developed through critique and ongoing empirical research, culminating in Zhang and Chin's 'structural deficiency perspective', which essentially locates in this same property of structure-control the failure of traditional triad societies to exploit transnational illicit market opportunities in trades such as human trafficking and heroin supply (Zhang and Chin 2003). These international globalized illicit markets are, for these authors, the domain of small, flexible, entrepreneurial groups of traders who are unbound to, or stepping outside of, conventional organized criminal structural bases, to 'somehow find one another for a few sporadic transnational operations' (Zhang and Chin 2003: 486) and, therefore, present a considerably more elusive target for law enforcement than larger and more stable organized crime groups. These are 'enterprising agents [with] no identifiable organisations, no rigid structure, no clearly defined deviant norms and values' (Zhang and Chin 2003: 485). Lo puts a social capital frame of analysis around these two perspectives on transnational organized crime, identifying high degrees of internal 'bonding capital' in traditional organized crime structures like triads, together with horizontal 'bridging' and vertical 'linking' capital providing opportunities for illicit enterprise via complicity respectively with other legitimate or illegitimate groups, or corrupt state interests (Lo 2010).

The research literature on trafficking in a variety of illicit markets has often supported the flexible, informal, small-scale trafficking model, somewhat in the face of an entrenched policy discourse that constructs the threat of transnational organized crime in considerably more fixed, structural, grand and opaque terms (Hobbs 1998; 2001; Woodiwiss and Hobbs 2009). This seems to have been the case in relation to much wildlife trafficking, for example where Naylor has identified in relation to the illicit ivory trade that "while much anti-animal trade rhetoric emphasises the alleged participation of "organised crime" in the clandestine traffic, the reality is that, not just with ivory, but with all wildlife trade, the illegal market is run (and always has been run) by the same actors who operate the legal one, and with the same infrastructure' (Naylor 2004). The high-level international policy discourse of illicit antiquities regulation has been criticized in similar terms for reliance on and promulgation of a language of organized criminal underworld, when equally if not more important must be questions of corruption, complicity and facilitation of illicit trade by apparently legitimate actors, since the insertion of looted artefacts into open public trading venues is clearly a core problem (Mackenzie 2011).

Looking across the literature on social networks and organized crime, we can note that Morselli's studies of criminal networks have premised the 'flexible order' in which both hierarchically and loosely structured settings of criminal enterprise subsist, in which 'criminal entrepreneurs' exploit 'brokerage configurations' that are essentially opportunity structures that arise out of criminal contacts and associations between potential co-offenders (Morselli 2005, 2009, 2013). And these social network theories of organized crime have been stressed by Asian area studies in the discipline, especially with regard to Chinese criminal syndicates where the emphasis has come to be on 'the superiority of familial and personal networks and fortuitous social contacts, with limited hierarchical structures' (Lo 2010: 868; and see also Williams and Godson 2002; Zhang and Chin 2002; Xia 2008).

The question, therefore, arises: to what extent are these theoretical developments in analysis of organized crime structural models applicable to the transnational 
illicit antiquities trade? We engage with that issue here, suggesting that commonplace claims about the eclipse of hierarchical organized crime enterprises by looser and shifting networks may not be universally accurate. Historical issues of military presence and control in Cambodia present a different context to that underscoring most research on trafficking and smuggling by Asian organized crime groups. Broadly stated, our conclusion will be that while the present case study is undoubtedly of a network, in which nodes, contacts and certain types of social capital are useful explanatory concepts, there is also an observable stability, and identifiable forms of hierarchy, both along the chain of the whole network and within each of its nodes. We conceptualize the network as a repetitive process, having developed by way of linking nodal actors in long-term trading relations, and harnessing the benefits at different stages in the chain of both localized territorial 'structure-controlled' organized crime and (as the trades move increasingly towards the transnational) more flexible entrepreneurial trafficker-dealers who are less tied into frameworks involving territory or group.

\section{Methodology}

In the summer of 2013, the authors travelled to Phnom Penh and from there toured the country by road, covering approximately $2,500 \mathrm{~km}$ before crossing into Thailand and finally departing from Bangkok. We were accompanied by a local contact who had been doing regional scoping research in the preceding year and was therefore able to introduce us to some potentially useful interviewees. We uncovered more interviewees ourselves during the course of fieldwork. We rotated three interpreters (one also an expert on the illicit antiquities trade) throughout our travels, so that we usually had two on site at any interview. This made conversation less stilted, since the first could ask our questions of the interviewee, while the second translated their responses. This approximated a free flowing 'normal' conversation as much as possible in an environment where locals spoke Khmer or Thai and usually no English.

We explored the network from the bottom-up, beginning at six major archaeological sites. These were Angkor (including the Roulous grouping and Banteay Srei), Banteay Chhmar (including Banteay Torp), Koh Ker, Phnom Banan, Preah Khan of Kompong Svay (the Bakan) and Sambor Prei Kuk. These represent a wide spectrum of Cambodia's ancient history, geography and current development. These sites are indicated on the map in Figure 1.

The oldest site (the city of Sambor Prei Kuk) dates back to the sixth century, while the latest (the monument of Banteay Torp) was modified as late as the 16th century. They thus include examples of two major religious traditions-Hinduism and Buddhismand a number of distinct artistic styles. Most were built during the height of the Khmer Empire, the Angkorian Period, from the 9th to 15th century. Several were the work of a single ambitious king, Jayavarman VII, who ruled from circa 1181 to 1218. In size, they range from a single temple (Phnom Banan) to ancient capitals with dozens of temples (Angkor, Koh Ker and Sambor Prei Kuk). In location, they span from the centre of the country, to the far north, to the far west. Some fell to the Khmer Rouge as early as 1970; some remained under their control until their 1998 surrender. Now, the most tourist 


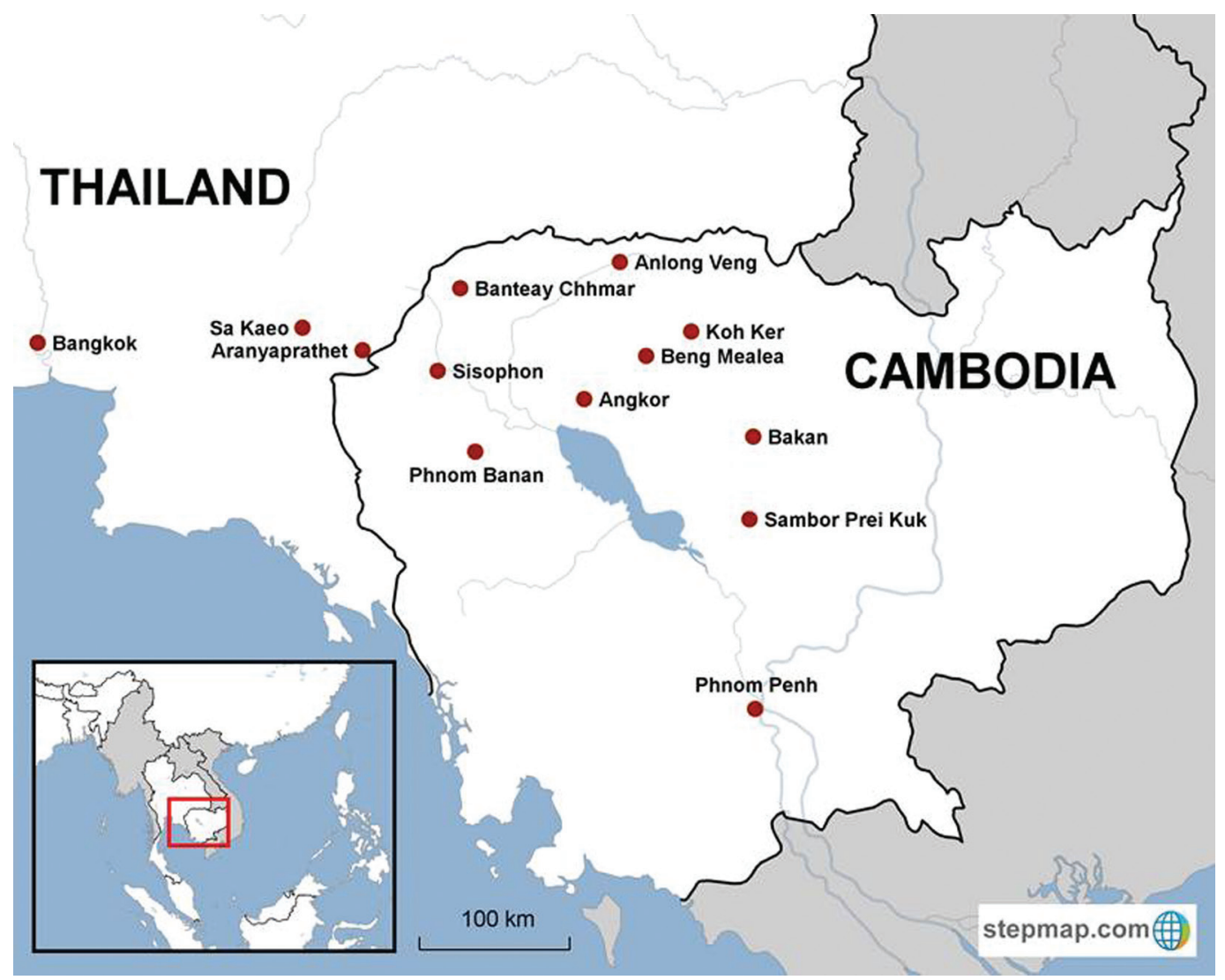

FIG. 1 Map of sites visited and key locations.

friendly (Angkor) is mere kilometres away from an international airport and welcomes millions of sightseers each year. The least accessible on our itinerary (Preah Khan of Kompong Svay) is so isolated that we had to approach four drivers before finding one willing to attempt the road, and not surprisingly, it receives only the most adventurous visitors. All are very much 'living' sites. This is most obviously the case at Angkor, where within the park's boundaries over 120,000 people inhabit 112 villages, some of which are said to be as ancient as the monuments themselves (Hauser-Schäublin 2001: 128). Even at the remote Preah Khan, there is a small community. Furthermore, each temple we surveyed is still used as a place of worship, and most have an active pagoda on the grounds or nearby.

We started our search for data at these temples, led by our local contact or by local guides. Aside from the latter's usual brochure-style recitations delivered on tours of the sites, they were also able to answer our more directed questions about the recent history of the area. These 'children of the temples', as they are called in Khmer, were mostly around 30 years old and, therefore, often had stories of growing up in the nearby village and witnessing looting first hand. These 30 year olds in Cambodia have known war for half their lifetime. While born after the Killing Fields (1975-79), they grew up in the Vietnamese Occupation (1979-89), when much of the country was still 
under Khmer Rouge control, or that of other paramilitary groups, or of course the Vietnamese themselves.

Another useful strategy we found for accessing local knowledge on looting, recommended by our local contact, was to go to a temple complex and seek out the 'oldest person in the village' or 'the person who knows stories about the village'. In some cases, this was the village or commune chief, or Buddhist monks or nuns. Even in a country where only 3.9 per cent of the population is over age 65, elders were quite easily found and were generally happy to sit down and talk to us about their community's relationship with the temple dating back to the colonial period. Some were able to point us to people who had witnessed looting, or even been involved in it, and thus might be better sources of information. Consultation with these individuals, especially those who had taken statues and other parts from temples, led to information about who had organized the looting ventures and/or where the objects had gone. ${ }^{1}$ This enabled us to move up the chain of supply.

All of the information we present here is historical, in the sense that the narratives we have gathered refer to the period from the mid-1960s to mid-2000s, with the majority of activity occurring during the 1970-98 Civil War. Few of the erstwhile looters we spoke to admitted involvement in contemporary trafficking. Some attributed this to their realization that disturbing sacred sites brings only bad luck, and feared their role in the illicit antiquities trade had cursed them, or worse their families. Others mentioned increased temple security, especially at the heavily guarded Angkor. Another explanation is that 'most of the good pieces have already gone'-which rings true to our site visits, where we accumulated many pictures of headless statues, pedestals from which statues have been broken off at the ankles and holes in walls where reliefs used to be.

As we shall see, however, remnants of the trafficking networks remain in place. We were told by a receiver at the Thai border that if we wanted any piece that was currently in situ, we should go and take a picture of it and he would arrange for it to be looted and delivered to us within a month. A number of archaeologists, conservators and curators have told the authors such 'theft on demand' was a common practice in the 1990s. So while the networked looting and trafficking activity we analyse here does seem to have abated somewhat in recent years, there is an open question around how much is still going on.

\section{The Network Structure}

In crude overview, we have established a picture of a funnelling network, which took statues from the various temples of Cambodia and passed them into a small number of channels that moved them by oxcart, truck and even elephant out of the country and into Thailand.

One of these channels operated from Cambodia's northwest (including the sites of Angkor, Banteay Chhmar, Koh Ker, Phnom Banan, etc.) through Sisophon, a town around $20 \mathrm{~km}$ from Thailand. From Sisophon, statues went through Poipet on the Cambodian side of the border to Aranyaprathet and Sa Kaeo on the Thai side. From

\footnotetext{
${ }^{1}$ While some knew more than others, every time we asked a local where looted Khmer antiquities go, the answer was always 'Thailand'. However, some expressed surprise upon learning that from there, Khmer antiquities have ended up in the United States, Europe and Japan.
} 
there, it is a straight drive up a main road to Bangkok-a journey that now can be made by car in three hours. In this article, we will outline the roles played by key traffickers identified in the course of our research. These criminals worked at the main points along this channel: at Koh Ker, in Sisophon and in Aranyaprathet. The routes involved in this channel are indicated in Figure 2.

Another channel used the due north border with Thailand, taking objects through the deep forests of the Kulen region and former Khmer Rouge stronghold of Anlong Veng on the Cambodian side, across the Dangrek Mountains which traverse that northern border, to Khun Han and Kantharalak on the Thai side. Again, from here, the statues move to Bangkok.

Each of these two channels has been confirmed by a number of different sources, so we can be reasonably secure in our view of the reliability of this information. However, we present these channels as illustrative rather than definitive. This is because we focused on Battambang, Banteay Meanchey, Kampong Thom, Oddar Meanchey, Preah Vihear and Siem Reap provinces, in other words, the central, northern and western areas of the country. Also the ethnographic methods of our research make it an opportunistic rather than a comprehensive survey. This raises the question whether, for example there might be different channels for objects originating in southern Cambodia: perhaps by sea through the port of Sihanoukville or overland to Vietnam. The greatest concentration of Angkorian temples is obviously centred on Angkor itself, but southern Cambodia is also archaeologically rich, especially with pre-Angkorian sites and the occasional Angkorian outpost such as Phnom Chisor. It is thus not surprisingly that Lafont (2004: 40) and Nagashima (2002: 107) both cite an antiquities smuggling route from this part of the country, through the port of Sihanoukville, to Singapore. Nagashima further reports that some pieces are then 're-exported' from there to Thailand before entering the Western art market (see also Thosarat 2001).

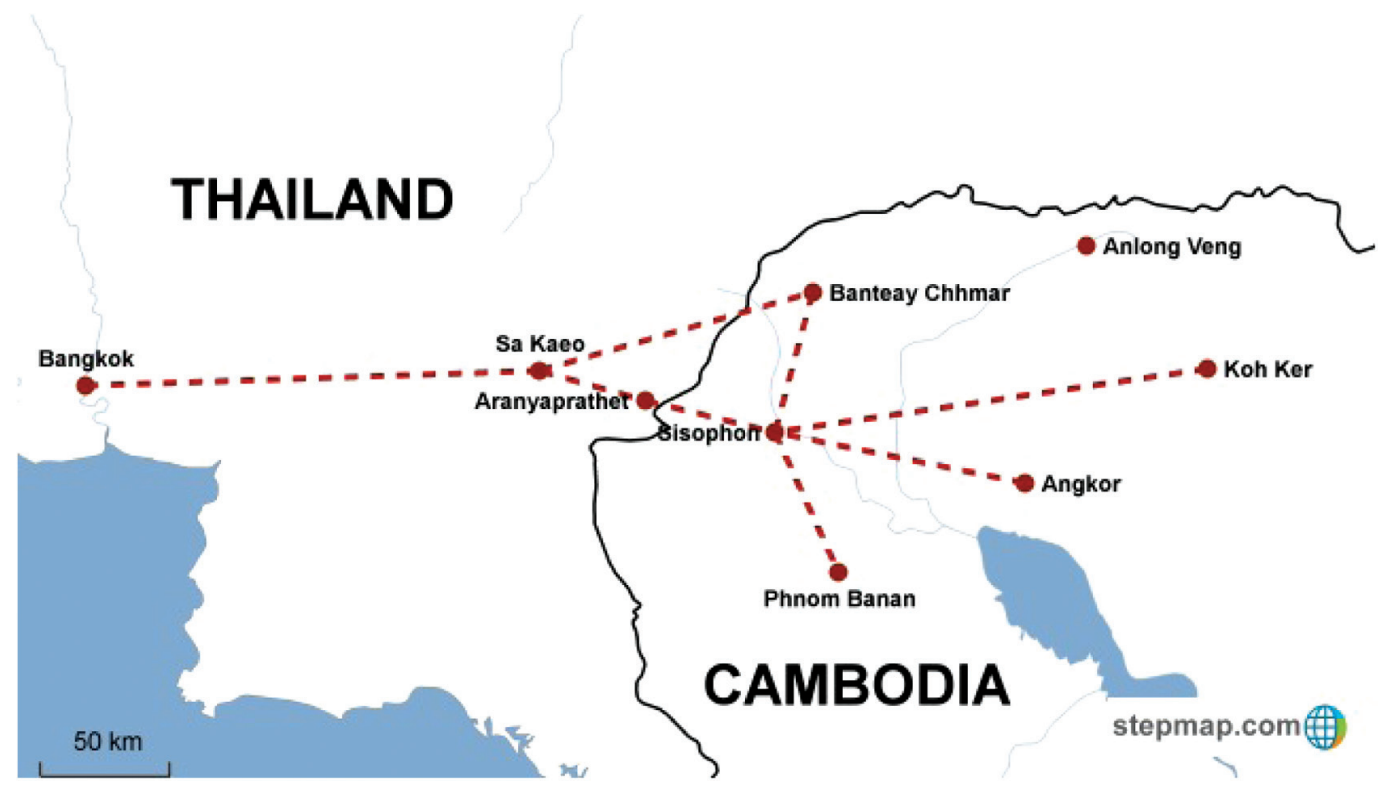

FIG. 2 Trafficking routes in the 'Channel 1' network. 
In this article, we will outline the processes of trafficking involved in the first channel mentioned above. A companion piece to this article will perform the same type of analysis for the other channel (Davis and Mackenzie 2014). The northwest channel we address here is in broad terms an 'organized crime channel': the major players in the early-stage traffic along this channel are identifiable as local gangsters. The northern channel, by contrast, was used by Khmer Rouge to move statues out of Cambodia and is therefore more amenable to analysis under the question that is often asked as to whether antiquities traffic funds armed conflict, rather than whether it is linked with organized crime, although of course the two questions are not mutually exclusive.

To foreshadow the main discussion in this article, the channel we identify here has four major network nodes (all names are pseudonyms):

(1) Thom, a regional 'broker', who organized the looting of statues and delivered them to Sisophon.

(2) Two organized criminals in Sisophon, Sambath and Phala, who acted as the northwestern hub for Cambodian statue traffic, buying from the regional brokers and delivering the loot to the border with Thailand.

(3) Rachana, a receiver on the Thai side of the border who would take delivery of the statues and move them to Bangkok.

(4) Kanok, an internationally connected dealer of statues in Bangkok, who was the 'Janus' interface between the licit and illicit trades.

\section{Temples: the Start of the Chain}

The 12th-century citadel of Banteay Chhmar is infamous in the academic literature for 'the most daring and devastating theft that ever took place in Cambodia' (Lafont 2004: 54). In late 1998, rogue Cambodian military surrounded the temple at dawn and blockaded it from the local community, with no explanation. The Cambodian generals responsible no doubt used the country's ongoing tumult to their advantage, as the Khmer Rouge was disintegrating near simultaneously, just $130 \mathrm{~km}$ away from Banteay Chhmar in Anlong Veng. For the next two weeks, heavy machinery was used to break up the complex and when the clamour finally stopped, soldiers loaded an estimated 30 tons of stone-including an entire $30 \mathrm{~m}$ of the southern wall, prized for its skilled bas-reliefs of Lokeshvara and Apsaras-onto six trucks and drive off for the Thai border just $15 \mathrm{~km}$ away. It is believed the convoy crossed at Ban San Ro Changan, where it was met by Thai dealers, who transported the antiquities on to Bangkok (Lafont 2004: 52-6).

Thai authorities stopped one of the trucks in Sa Kaeo province and seized over a hundred antiquities, including an 11.5-m span of wall. The two drivers were arrestedand eventually tried and convicted-despite denying knowledge of their illegal cargo. They likewise could not (or feared to) identify who had hired them or to whom they were delivering their shipment. There were no further prosecutions, even though an investigation later identified the Cambodian generals responsible and further implicated the military in other thefts (Phnom Penh Post 1999). After over a year of political wrangling between Cambodia and Thailand, the seized pieces were finally returned to Phnom Penh. But the rest of haul from Banteay Chhmar which escaped in the other five trucks has, aside from a few opportunistic recoveries, disappeared into the art market. 
While scholars and journalists have described the 1998 heist as unprecedented, we learned instead that it is fairly representative of the history of looting at Banteay Chhmar and just the tip of the iceberg in terms of looting across the country. Village elders at Banteay Chhmar told us that in their youth there were many statues in and around the temple (a fact confirmed by colonial accounts and photographs). Then in the early 1970s_-during an attack foreshadowing that in 1998-soldiers from the US-backed Lon Nol army closed off the complex, raided it during the night and carried off their spoils by helicopter. The next years are a question mark, as the villagers were displaced during the 1975-79 Killing Fields, and many also spent the subsequent years of occupation and famine in Thai refugee camps. Those present in the 1980s and onwards, however, report a revolving door of armies-from the Khmer Rouge, to paramilitary groups, to government forces-that ended only with the Civil War in 1998.

During this time, local villagers were 'invited' (in the sense of 'instructed') to loot the temple at night by these various armed factions, who effectively functioned as gangmasters for this looting enterprise. Local men were offered 300 Thai Baht (today approximately US\$7, though in the $1990 \mathrm{~s}$, it would have been closer to $\$ 12$ ) per night to work on the effort and faced violent intimidation and possibly death if they refused. One source in the village said it was not a difficult choice, if it can be called that, and that he and many of his friends had become looters.

The looters at Banteay Chhmar report having witnessed Thai dealers (up to four at a time) negotiate the purchase of pieces with the military chiefs who were organizing the looting gangs. Again, Banteay Chhmar is very close to both Cambodia's northwest border with Thailand $(15 \mathrm{~km})$ and the large town of Sisophon $(60 \mathrm{~km})$, an integral stop on the path taken by objects running along the first looting channel we identified. The looted statuary of Banteay Chhmar thus crossed into Thailand both ways-in some cases directly and in some cases through Sisophon.

Nowadays, there is little left to steal. During our visit, we did not see a single intact statue. Archaeologists do hope some have survived inside the complex, protected under the tons of collapsed architecture, but it is possible looters have reached these as well. The large perimeter wall is really all that visibly remains, and it is still impressive in its structure and artistic adornment. One can see how it would make an attractive target for organized looters with the capacity to lift and carry away heavy chunks of it, as happened in 1998.

Just as the 1998 incident is representative of looting at Banteay Chhmar, so too is the looting at Banteay Chhmar representative of that throughout the country. We learned the basic elements were repeated, in varying forms, at all the temples we visited. Locals report that each of these sites had been well protected in the colonial era and early years of independence (1800s-1960s). In most cases, organized looting and trafficking is only remembered as beginning around 1970, with the start of the Civil War. There is no little irony in the observation that 1970 was also the date of the culmination of successful negotiations around the landmark United Nations Educational, Scientific and Cultural Organization Convention, which in that year drew countries together in recognition of the need to protect the cultural heritage of humanity against plunder and illicit trade (UNESCO 1970). In Cambodia, the plunder would remain closely tied to the conflict through to the 1998 surrender of the Khmer Rouge, with heavy involvement from the various armed forces in the country (including the Cambodian military, paramilitary groups and the Khmer Rouge). 
These groups would use local labour (willing and unwilling, paid and unpaid) when needed. From the temples, the pieces would be carried by oxcart, truck/military truck and occasionally even helicopter or elephant to the border. From there, they would go to Bangkok, often with the help of Thai military. Importantly, however, although we note that the traffic was 'closely tied to the conflict', this does not mean that looting and trafficking was the exclusive preserve of military groups. As we shall turn to discuss now, organized criminals with no military affiliations were active in the looting of Cambodia, as were others with fleeting or otherwise non-committal ties to a particular armed faction.

\section{The Role of Regional Brokers}

By accessing villagers near the temple sites_as we did at Banteay Chhmar and others-we moved up the trafficking chain. In particular, our local contact led us to a 'broker' (his term for himself), whose organized crime activities included controlling the regional looting network. We received a wealth of richly detailed information from this broker, Thom, which first led us to realize the importance of Sisophon as the Cambodian hub for cross-border traffic to Thailand down the north-west channel. Thom, and subsequently others, described this town as the main portal between the regional Cambodian brokers like himself and the Thai border trade.

Thom ran the temple looting network in a region containing Mount Kulen and Koh Ker, as well as countless other archaeological sites. The territorial limits of his 'jurisdiction' were quite precisely defined; so much so that he was able to identify a street corner in a particular town where 'his' territory ended. He controlled the looting in this area in partnership with another man-each region, he said, had two brokers who controlled it together. His relationship with his partner was based on what he described as a very high level of trust.

Thom had grown up in this region, but was forced into the military at age 11, during the early years of the Civil War. His ability to ride a horse earned him the coveted post of Khmer Rouge messenger, tasked with delivering missives between their regional camps. In his teenage years, he graduated within the Khmer Rouge from messenger to soldier. At the height of the purges, Thom defected from the Khmer Rouge, fleeing to the jungles of Kulen. For three years, he remained there in hiding, often taking shelter in temples (knowledge that would serve him well in later years). After the Vietnamese overthrew the Khmer Rouge in 1979, weary of war and regretful of his part in it, Thom resolved to do something with his life that did not involve so much death, thus began his career in statue trafficking.

In the 1980s, he began this enterprise as a solo effort, knowing little about what he was doing but learning what he needed to from his uncle, who was already an active statue trafficker. He described to us his very first venture, in which he took a large and valuable statue from a nearby temple but sold it for only 50 Cambodian Riel. This is less than a penny in today's currency, but even in the 1980s, it would have been mere dollars at most.

Desperately in need of money, facing poverty and starvation, Thom's family helped him to improve his skills as a looter. As well as his uncle having first-hand knowledge of statue theft, his father-in-law was a former cultural official and had given him an 
illustrated Khmer art history book, from which he learned a great deal, despite being illiterate. Over the course of his trafficking career, he would develop an expert eye for statuary. We showed him catalogues of Khmer ancient art and he was able to quickly and accurately identify objects from only the pictures by their date and style ('12th century', 'Angkor Wat Style' and so on). He recognized several of the objects, now in established collections outside Cambodia, as some of those he had been involved in trafficking.

As the 1980s passed, he developed his trading business. He joined forces with his partner and they began to become more organized by recruiting people to work for them. Over time, the two men established a gang, which Thom says at its height had 'a thousand' people in it. This is probably an exaggeration and is in part explained by the somewhat loose-knit practical arrangement of his network of workers described below.

In Thom's looting operation, there is a clear hierarchy, with Thom and his partner at the top, and a relatively small group of colleagues around them who we might think of as forming the second tier. But below this, there is a much more fluid and opportunistic network-type structure. Thom would drive around the region in the morning, picking up willing participants for that day's looting. In some cases, he would order local villagers to take part where they would otherwise have been unwilling, and they would obey through fear of his reputation for violence. He would generally pay the willing participants, but not the unwilling ones.

The enterprise was, therefore, characterized in the field by flexible groups of casualized looters, looking somewhat like a contemporary 'zero-hours' contract arrangement where an employee is always available to work but only gets paid for the hours they actually put in. On many days, the looting groups would be large in number; Thom describes one particularly heavy statue which took 40 men to carry. Having to pay all of these workers led to an escalation in the amount of looting and traffic, both through high capacity to undertake thefts and movement and also through business prerogatives-Thom ruefully described how his sense of fairness in wanting to pay all of his workers meant that he 'had to steal more' in order to make sufficient profits. When asked about an average example of the split of proceeds, he recalls one statue sale where he took 1500 baht for himself and paid each of his six gang members involved in that theft 600 baht. In his general recollection, he reported that quality pieces would fetch $5,000,20,000$ or even 40,000 baht (about $£ 750$ in today's prices).

Thom found it difficult to say how many statues he had trafficked in his career, which was active from the 1980s until recently. While leafing through the Khmer antiquities catalogues we had brought to show him, he would occasionally point to modestly sized pieces in bronze and say that he had found 'thousands' like them. When pressed to put a number on the volume of his activity, he stressed that like any business, some years were better than others. For example, 1994-96 was a bad period, due to heavy fighting in the region. But he remembered mid-1997 to mid-1998 as a 'good year' for looters, as the ongoing collapse of the Khmer Rouge opened up the country for the safer internal movement of people and goods. In that 12-month period, he estimated his group had trafficked 92 statues. Some of the objects his network handled were pieces that are now celebrated as among the most important Khmer statues in world collections. For example, he has identified several major statues that he took from the Prasat Krachap temple at Koh Ker. 


\section{On to Sisophon}

Thom and numerous others identified a main channel as the preferred route for trafficking Khmer art out of the country. It funnelled antiquities from Cambodia's archaeologically rich northwest to Sisophon. From here, smugglers would travel along Highway 5 to the border, crossing at Poipet/Aranyaprathet.

Two brothers who were dealers in Sisophon were the Cambodia-side destination for objects passing through this channel. They were individually attached to different military factions, but they worked together on the trafficking business. We learned that such cooperation between enemy factions was typical, and while Cambodia's various armed forces refused to govern together, some of their soldiers had no problem doing business together. Both Sambath and Phala are remembered by locals as running a wide range of illicit enterprises as well as statue traffic, including drug smuggling and prostitution. One of the brothers, Phala, is now deceased, while the other brother is still alive and runs a business in Sisophon. He is widely feared for his violent reputation, having reportedly killed many people in disputes over the brothers' illicit businesses.

In the days when Sambath and Phala were in business together, Sambath was 'the money man' and Phala was 'the delivery man' in the statue traffic. Sambath would collect payments from the receivers above them in the network chain, and Phala would deliver the statues from Sisophon to the Thai border, often using military trucks that he had access to through his affiliation with a paramilitary faction.

Thom, the regional broker introduced above, was one of those who supplied Sambath and Phala. Further, Thom and others told us that the 1998 Banteay Chhmar looting detailed above had been organized by Phala. Although Sambath and Phala were Cambodians, they both spoke Thai, so this may explain the reports from the looters we met at Banteay Chhmar that the statues taken from the temple had gone to 'Thai dealers'. The Cambodian/Thai border has in any event long been porous, and frequently disputed, with some provinces having gone back and forth between the two countries multiple times over the last centuries. As a result, there are many native Khmer speakers on the Thai side of the border, and vice versa. The aggregate of all the various reports we received from interviewees on Sambath and Phala therefore seems to place them as a major node in the Cambodian trafficking network, with a number of regional lines of supply connecting to the Thai border through them.

Thom also told us that Sambath had organized the killing of his uncle. The uncle had attempted to cut Sambath and Phala out by taking one of Thom's looted statues direct to the Thai border and trying to sell it to the dealer Kanok we mention below. Kanok declined, apparently concerned with repercussions that might arise if Sambath and Phala found out. They did, and the uncle was shot shortly afterwards at Sambath's business premises. Thom himself had once taken a statue up the northern route in an attempt to cut Sambath and Phala in Sisophon out of the deal. When he tried to sell the statue to the dealer Kanok in Kantharalak, Kanok insisted on including in the price the normal commission which Sambath and Phala would charge had the statue passed along their supply channel and which he duly remitted to them. This left Thom with the impression that attempting to circumvent the operations of the north-western border channel was fruitless 
and also that Kanok himself seemed to be concerned not to cross the dealers in Sisophon.

The normal procedure for arranging traffic up the network from ground to the border was that Thom would send Sambath and Phala photos of the objects his gang had looted or sometimes pre-looting photos of objects in situ. An offer would come down the line from Sisophon with a price. This price was open to marginal negotiation but was generally not very flexible. Although the art crime literature regularly discusses the possibility of 'theft to order', Thom said that this never happened in the course of his involvement in the traffic in as specific a way as the literature has sometimes imagined. In other words, photos would be sent up the chain saying 'we have stolen this, would you like to buy it', but photos of statues in situ never came down the chain saying 'please steal this'. The closest arrangement to this latter possibility was that occasionally requests would come down to supply a particular type of statue, but these were general types rather than specifically identified artefacts. ${ }^{2}$

\section{The Thai-Side Border Trade}

At the Thai border, the objects were received by people reported to us to be variously 'Thai dealers' or 'the Thai army'. We attempted to get more specificity on this link in the chain by travelling to Aranyaprathet on the Thai side of the border and the smaller town of Sa Kaeo, which is arranged along both sides of the highway that leads from 'Aran', as the locals call it, to Bangkok. In Aran, we met the owner of an antiquities shop and hotel, Rachana, who suggested that he was Thailand's premier faker of ancient statues. He had also been the main receiving point for objects coming across the border from Sambath and Phala, working with a general in the Thai military, and in his own words having 'seen every statue that came from Cambodia in the last thirty years'. Rachana mixed his trafficking business with a faking business, which in some cases supplied the same customers. From Aran, he was able to sell the looted and fake objects relatively freely to buyers in Bangkok who could transport them out of the country without obstruction. There has been, and remains, no appetite at Thai customs for restricting the export of any country's cultural heritage other than their own Buddhist pieces, and the export of fakes is not prohibited by law.

Fakes are a difficult concept in Cambodian statues. From high-end shopping complexes for antiquities like Rivercity in Bangkok, down to street stalls in the city's Chatuchak market, fakes are in abundance. They are marketed under a number of different names, however, and rarely called fakes explicitly. Instead, we find apparently oxymoronic labels like 'genuine reproductions' or 'modern ancient art'. Rachana, the receiver in Aran, had a team of 20 Cambodian fakers working for him, reproducing old statues using a variety of techniques to artificially give them the impression of age. After manufacture, statues were buried in the ground for between six months and five years to give them a musty patina, so that when sprayed with water they would give off a smell suggesting they were older. Rachana suggested he supplied '40-50 per cent' of the tourist outlets at Rivercity. When describing his creations, he did not use the Thai word for 'fake' but called them 'copies' which, in the context he used it, suggested an

\footnotetext{
${ }^{2}$ Note this is in contrast to what the Thai dealer Rachana said when he offered us theft to order in 2013.
} 
artistic process involving respect for the older original pieces and a legitimate attempt to recreate their genius.

A few miles up the highway from Aran towards Bangkok is Sa Kaeo, a town that everyone will have to pass through who is taking the border-crossing land route from Poipet in Cambodia to Bangkok. Lining the highway and with nothing to recommend it other than its location along a main thoroughfare near the border, this has always been a town of traders-before statues, it was other types of goods. People in Sa Kaeo remember trucks, many of them military vehicles, filled with looted statues rolling through the town on their way to Bangkok from the 1970s until around ten years ago. Locals report that 'everyone' in the town was involved in the statue trade and that the richest people in the town earned their money originally through buying and selling looted statues. A major regional dealer is still based in the town, running a hotel with 'secret' rooms where major pieces of looted statuary are available for viewing by interested buyers. As with so many 'secrets' in this trade, and indeed in this region, these are things that are widely known and easily confirmed. As well as the organized border trade involving Sambath, Phala and Rachana, there was a more disorganized trade where poor Cambodians would arrive at the border needing food and medicine with statues to sell by way of payment.

\section{Bangkok}

A dealer, Kanok, had been a major buyer of looted statuary in Bangkok for decades, via both the channel we have outlined here and the second northern channel we address elsewhere. Thom, the regional broker, thought Kanok to be the main buyer of all the looted statues travelling down the north-western channel. Thom remembered Kanok to have tight links with the Thai military, so all the Cambodian side of the network had to do was to get the objects to the border and they would be delivered from there to Kanok by the military-dealing network on the Thai side. There were a small number of other such high-end high-volume Thai dealers too, and some of these were suppliers of Kanok, as well as dealers for other clients. Thom noted with some resignation that there was a considerable widening of profit margin on transactions further up the chain, so that one of Kanok's main Thai dealers/associates was now very rich and had relocated to the United States, whereas Thom was still exactly where he had been all his life, albeit in slightly more comfortable accommodation than some of his neighbours.

Rachana, the dealer in Aran, cited Kanok as a major customer of both fakes and the genuine looted pieces. Kanok commissioned Rachana to make fakes for him and as Kanok was renowned for having one of the best eyes in the business, Rachana took great delight in telling us about the time Kanok visited his outlet and after some appraisal declared a piece to be genuine when it was in fact a fake that Rachana had produced at Kanok's behest, but which Kanok had forgotten about. After speaking to people who had observed, supplied or worked for Kanok, a recurring suggestion seems to be that Kanok was commissioning these fakes to sell, or donate to museums. As one source put it, he 'loved the objects too much' and so could not bear to part with the original pieces he had acquired-thus the suspicion this source held that he had them copied and donated or sold the copies instead. 
On the road from Phnom Pehn to Kampong Thom, we met another master faker who had produced works for Kanok. He had produced over 100 fake statues for Kanok alone and had at one point been flown to Bangkok by Kanok so that he could do his work there to remove the problems of transporting the fakes out of Cambodia.

\section{Conclusion}

How does the network identified here fit with the models of organized crime groups/ networks identified in the general literature on 'the organization of serious crimes for gain' (Levi 2014), and further and more narrowly, how does it fit with the commodityspecific models proposed in the transnational crime literature concerned with trafficking cultural objects, reviewed at the outset of this article, which consider the trade as a role-differentiated network taking the form (1) looter, (2) early-stage dealer, (3) late-stage dealer and (4) buyer?

The structure of the network identified here seems in some respects to support Lo's (2010) arguments for a progression from theories of 'structure-control' versus 'social network' towards a 'social capital' approach, which he suggests can incorporate previous observations on group and network, while also adding a layer of explanation around political dynamics as they support and affect the development of social networks and organized crime. Importantly, the social capital approach allows us to acknowledge a picture in which both groups and networks exist, with regionally bounded and in Lo's terms 'bonded' (structure-controlled) groups interfacing with a network of transnational actors who become more flexible in their trading partners-and therefore look more like a social network and less structure-controlled-the further up the chain towards the market we progress, using bridging (horizontal) social capital to pass looted and fake statues through the variety of market channels in Bangkok. The involvement of corrupt military officials and the complicity of other powerful actors may appear to be a form of linking (vertical) social capital. But there are also many elements of the analysis that seem to continue to demand a more traditional structure-control approach to explanation. We conclude by looking a little more closely at this issue through the framework of the role-differentiated models proposed for antiquities trafficking chains.

At Stage 1, we have Thom and his gang. Thom is an 'organized' looter, but some of his employees may be better classed as volunteers looking for a modest daily rate of pay-not quite the subsistence diggers of the illicit antiquities literature (Matsuda 1998), but not serious profiteers either. Thom is also a broker, or as some other models have it an 'early-stage middleman'. Sambath and Phala are also 'early-stage middlemen', however, so clearly some distinction is required between levels of early-stage middlemen. Likewise, the Thai border traders are also (later-stage still) early-stage middlemen. Only when we get to Kanok in Bangkok do we arrive at a late-stage middleman-but Kanok is also a collector, so he confuses somewhat the last two steps in the four-stage model. It becomes clear therefore that the models previously proposed are identifying roles which (1) can be filled on several levels by multiple individuals or groups, leading in some stages to more trades in a network chain than are suggested by the models in their basic form and (2) the opposite is also true, in that one individual or group can occupy multiple roles. Indeed, the proponents of these models have recognized this dimension to them. 
Of the first-'looter'-stage in his model, Campbell says 'sources show there is no representative type of participant... revealing that any individual presented with a profitable opportunity might be inclined to participate' (Campbell 2013: 125). Our data add some context to that rather asocial opportunity-theory-based rational choice position on the matter (Felson and Clarke 1998). As might be expected, looting choices are made in a culturally situated social space where personal decisions are cast in light of personal and group-based historical influences including in particular in our case study traumatic participation in war and mass killing for Thom, and threats made for non-participation against some members of his workforce. It is not just 'any individual' who appears in this role-in our case, Thom's personal journey was important as was the social learning aspect of picking up the routines of the trade from his uncle, who was already involved. In some senses then, a deeper understanding of participants' life histories allows us to see the 'pathway' rather than mere 'opportunity' elements of the process of 'becoming' a statue trafficker.

On the second and third stages of his model-early- and late-stage intermediariesCampbell says 'observable trends show that even this stage is variable, with early-stage intermediaries regularly using different late-stage intermediaries. Interactions generally consist of single exchanges of capital and goods with no promise of long-term agreements... In contrast to hierarchical structures, participants in the trade have no fear of sanctions if further interactions do not occur...' (Campbell 2013: 125). Yet our research has uncovered a trafficking channel that was essentially fixed for several decades, in terms of its roles, the occupants of those roles and their trading relationships. Where occasionally an individual may have tried to step outside of the norms of this trafficking chain, they experienced sanctions from the established hierarchy, which either quickly brought them back into line or resulted in their being used as examples to others not to try similar innovations. The involvement of organized criminals in this supply chain has precisely had the effect of encouraging the "promise of long-term agreements' on pain of violent repercussions in the case of breach, since such stable sources of income generation are the life blood of illicit business.

For various reasons, therefore, it can be suggested that based on this case study evidence, antiquities trafficking 'networks' might be thought of as more stable, hierarchical and repetitively functioning supply chains than the highly fluid picture that has been developed both in the general organized crime literature and in recent papers in the illicit antiquities sub-field. Clearly, much more primary empiricism needs to be done to adequately verify this pattern as being generally representative rather than just a regional historical observation. It seems, however, that to say that 'the illicit antiquities trade can be usefully explained through the network paradigm. Hierarchical organisation does not appear to exist currently within the trade' (Campbell 2013: 138) is to overlook the stability of organized criminal routines in the early stages of the network, which certainly entail hierarchies of an important kind. It also seems to misdiagnose the Janus role as an opportunistic networked transition point for illicit objects, seeing it as the exploitation of a passing profitable opportunity rather than a pinnacle of the organized crime hierarchy, driving an illicit market in important practical ways that have previously been thought to be better identified at the very end point of the supply chain via widely supported statements that embody the sentiment that 'collectors are the real looters' (Elia 1993; Renfrew 1993). In the trafficking network under study in this article, it might equally be thought to be Janus who is the real looter. 
MACKENZIE AND DAVIS

\section{Funding}

This work was supported by the European Research Council under the European Union's Seventh Framework Programme (FP7/2007-2013)/European Research Council Grant agreement no. 283873 GTICO.

\section{ACKNOWLEDGEMENT}

We thank our colleague and research assistant Naren Than for helpful comments on an earlier draft of this article.

\section{REFERENCES}

Atwood, R. (2004), Stealing History: Tomb Raiders, Smugglers, and the Looting of the Ancient World. St Martin's Press.

Bator, P. M. (1982), 'An Essay on the International Trade in Art', Stanford Law Review, 34: 275.

Bowman, B. A. (2008), 'Transnational Crimes Against Culture: Looting at Archaeological Sites and the 'Grey' Market in Antiquities', Journal of Contemporary Criminal Justice, 24: $225-42$.

Brodie, N. and Bowman Proulx, B. (2013), 'Museum Malpractice as Corporate Crime? The Case of the J. Paul Getty Museum', Journal of Crime and Justice, available online at http://www.tandfonline.com/doi/full/10.1080/.U4YYgRYWzRo.

Brodie, N., Dietzler, J. and Mackenzie, S. (2013), 'Trafficking in Cultural Objects: An Empirical Overview', in S. Manacorda, ed., Prevenzione e Contrasto dei Reati Contro il Patrimonio Culturale: la Dimensione Nazionale ed Internazionale. Vita e Pensiero.

Bruns, B. and Miggelbrink, J. (eds) (2012), Subverting Borders: Doing Research on Smuggling and Small-Scale Trade. Springer.

Campbell, P. B. (2013), 'The Illicit Antiquities Trade as a Transnational Criminal Network: Characterizing and Anticipating Trafficking of Cultural Heritage', International Journal of Cultural Property, 20: 113-53.

Chippindale, C. and Gill, D. J. W. (2000), 'Material Consequences of Contemporary Classical Collecting', American Journal of Archaeology, 104: 463-511.

Davis, T. (2011), 'Supply and Demand: Exposing the Illicit Trade in Cambodian Antiquities Through a Study of Sotheby's Auction House', Crime, Law and Social Change, 56: 155-74.

Davis, T. and Mackenzie, S. (2014), 'Crime and Conflict: Temple Looting in Cambodia', in J. Kila and M. Balcells, eds, Cultural Property Crime. Brill.

Elia, R. J. (1993), 'Ricardo Elia Responds', Archaeology, 46: 17.

Farchakh BajJaly, J. (2008a), 'Who are the Looters at Archaeological Sites in Iraq?', in L. Rothfield, ed., Antiquities Under Siege: Cultural Heritage Protection After the Iraq War. AltaMira.

- - (2008b), 'Will Mesopotamia Survive the War? The Continuous Destruction of Iraq's Archaeological Sites', in P. G. Stone and J. Farchakh Bajjaly, eds, The Destruction of Cultural Heritage in Iraq. Boydell Press.

Felch, J. and Frammolino, R. (2011), Chasing Aphrodite: The Hunt for Looted Antiquities at the World's Richest Museum. Houghton Mifflin Harcourt. 
Felson, M. and Clarke, R. V. (1998), 'Opportunity Makes the Thief: Practical Theory for Crime Prevention', Policing and Reducing Crime Unit, Police Research Series Paper 98. Home Office.

Gill, D. J. W. and Chippindale, C. (1993), 'Material and Intellectual Consequences of Esteem for Cycladic Figures', American Journal of Archaeology, 97: 602-73.

Hauser-Schäublin, B. (ed.) (2001), World Heritage Angkor and Beyond: Circumstances and Implications of UNESCO Listings in Cambodia. Universitätsverlag Göttingen.

Hobss, D. (1998), 'Going Down the Glocal: The Local Context of Organised Crime', The Howard Journal of Criminal Justice, 37: 407-22.

- - (2001), 'The Firm: Organisational Logic and Criminal Culture on a Shifting Terrain', British Journal of Criminology, 41: 549-60.

Hornsby, R. and Hobbs, D. (2007), 'A Zone of Ambiguity: The Political Economy of Cigarette Bootlegging', British Journal of Criminology, 47: 551-71.

Kelly, R. J., Maghan, J. L. and Serio, J. D. (2005), Illicit Trafficking: A Reference Handbook. ABC-CLIO.

Kersel, M. M. (2007), 'Transcending Borders: Objects on the Move', Archaeologies: Journal of the World Archaeological Congress, 3: 81-98.

Lafont, M. (2004), Pillaging Cambodia: The Illicit Traffic in Khmer Art. McFarland.

LeE, M. (2011), Trafficking and Global Crime Control. Sage.

Levi, M. (2014), 'Thinking About Organised Crime: Structure and Threat', The RUSI Journal, 159: 6-14.

Lo, T. W. (2010), 'Beyond Social Capital: Triad Organized Crime in Hong Kong and China', British Journal of Criminology, 50: 851-72.

Mackenzie, S. (2005), Going, Going, Gone: Regulating the Market in Illicit Antiquities. Institute of Art and Law.

- (2011), 'The Market as Criminal and Criminals in the Market: Reducing Opportunities for Organised Crime in the International Antiquities Market', in S. Manacorda and D. Chappell, eds., Crime in the Art and Antiquities World: Illegal Trafficking in Cultural Property. Springer.

Matsuda, D. (1998), 'The Ethics of Archaeology, Subsistence Digging, and Artifact Looting in Latin America: Point, Muted Counterpoint', International Journal of Cultural Property, 7: 87-97.

Morselli, C. (2005), Contacts, Opportunities and Criminal Enterprise. University of Toronto Press.

- - (2009), Inside Criminal Networks. Springer.

- - (ed.) (2013), Crime and Networks. Routledge.

Nagashima, M. (2002), The Lost Heritage: The Reality of Artifact Smuggling in Southeast Asia. Post Books.

NAYlor, R. T. (2004), 'The Underworld of Ivory', Crime, Law and Social Change, 42: 261-95.

Nordstrom, C. (2007), Global Outlaws: Crime, Money and Power in the Contemporary World. University of California Press.

Nørskov, V. (2002), Greek Vases in New Contexts: The Collecting and Trading of Greek Vases-An Aspect of the Modern Reception of Antiquity. Aarhus University Press.

Paredes Maury, S. (1996), 'Surviving in the Rainforest: The Realities of Looting in the Rural Villages of El Peten, Guatemala', Report Submitted to the Foundation for the Advancement of Mesoamerican Studies, Inc, available online at http://www.famsi.org/reports/95096/950 96ParedesMaury01.pdf (version current at 7 September 2013). 
Phnom Penh Post (1999), 'The Raiders of Banteay Chmar', available online at http://www. phnompenhpost.com/national/raiders-banteay-chmar (version current at 11 April 2014). Polk, K. (2014), 'The Global Trade in Illicit Antiquities: Some New Directions?', in L. Grove and S. Thomas, eds, Heritage and Crime: Prospects, Progress and Prevention. Palgrave Macmillan.

Renfrew, C. (1993), 'Collectors Are the Real Looters', Archaeology, 46: 16-7.

Staley, D. P. (1993), 'St Lawrence Island's Subsistence Diggers: A New Perspective on Human Effects on Archaeological Sites', Journal of Field Archaeology, 20: 347-55.

Thosarat, R. (2001), 'Report From Southeast Asia', Culture Without Context, 8: 18-21.

UNESCO (1970), Convention on the Means of Prohibiting and Preventing the Illicit Import, Export and Transfer of Ownership of Cultural Property. UNESCO.

van Schendel, W. and Abraham, I. (eds) (2005), Illicit Flows and Criminal Things: States, Borders and the Other Side of Globalization. Indiana University Press.

van Velzen, D. T. (1996), 'The World of Tuscan Tomb Robbers: Living With the Local Community and the Ancestors', International Journal of Cultural Property, 5: 111-26.

Watson, P. (1997), Sotheby's: The Inside Story. Bloomsbury.

Watson, P. and Todeschini, C. (2006), The Medici Conspiracy: The Illicit Journey of Looted Antiquities - From Italy's Tomb Raiders to the World's Greatest Museums. Public Affairs.

Williams, P. and Godson, R. (2002), 'Anticipating Organized and Transnational Crime', Crime, Law and Social Change, 37: 311-55.

Woodiwiss, M. and Hobbs, D. (2009), 'Organized Evil and the Atlantic Alliance: Moral Panics and the Rhetoric of Organized Crime Policing in America and Britain', British Journal of Criminology, 49: 106-28.

XIA, M. (2008), 'Organizational Formations of Organized Crime in China: Perspectives from the State, Markets and Networks', Journal of Contemporary China, 17: 1-23.

Zhang, S. and Chin, K.-L. (2002), 'Enter the Dragon: Inside Chinese Human Smuggling Organizations', Criminology, 40: 737-68.

- - (2003), 'The Declining Significance of Triad Societies in Transnational Illegal Activities', British Journal of Criminology, 43: 469-88. 